\title{
Complement Regulates CD4 T-Cell Help to CD8 T Cells Required for Murine Allograft Rejection
}

\author{
Mark Vieyra, ${ }^{*}$ Staci Leisman, ${ }^{*}$ Hugo Raedler, \\ Wing-Hong Kwan, ${ }^{*}$ Min Yang, ${ }^{*}$ Michael G. Strainic, ${ }^{\dagger}$ \\ M. Edward Medof, ${ }^{\dagger}$ and Peter S. Heeger ${ }^{\star}$ \\ From the Renal Division, "Department of Medicine, Mount Sinai \\ School of Medicine, New York, New York; and the Institute of \\ Pathology, ${ }^{\dagger}$ Case Western Reserve University, Cleveland, Obio
}

\begin{abstract}
Although induction of CD8 T-cell responses to transplants requires CD4-cell help, how this help is transmitted remains incompletely characterized. In vitro, cognate interactions between $\mathrm{CD} 4 \mathrm{~T}$ cells and dendritic cells (DCs) induce $\mathrm{C} 3 \mathrm{a}$ and $\mathrm{C} 5 \mathrm{a}$ production. $\mathrm{CD8}^{+} \mathrm{T}$ cells lacking $\mathrm{C} 3 \mathrm{a}$ receptor $(\mathrm{C} 3 \mathrm{aR})$ and $\mathrm{C5}$ a receptor $(\mathrm{C5} \mathrm{aR})$ proliferate weakly to allogeneic DCs despite CD4 help, indicating that CD4-cell help is mediated, in part, through DC-derived $\mathrm{C} 3 \mathrm{a} / \mathrm{C} 5 \mathrm{a}$ acting on $\mathrm{CD8}^{+} \mathrm{T}$ cellexpressed C3aR/C5aR. In support of this concept, augmenting DC $\mathrm{C} 5 \mathrm{a} / \mathrm{C} 3 \mathrm{a}$ production bypasses the requirement for CD4- and CD40-dependent help to wild-type $\mathrm{CD8}^{+} \mathrm{T}$ cells. CD4-deficient recipients of allogeneic heart transplants prime weak CD8 responses and do not acutely reject their grafts. In contrast, CD4-deficient chimeric mice possessing decay accelerating factor deficient $\left(\right.$ Daf1 $\left.^{-/-}\right)$bone marrow, in which DC C3a/C5a production is potentiated, acutely reject transplants through a CD8 cell-dependent mechanism. Furthermore, hearts transplanted into $C D 4 O^{-/-}$mice prime weak CD8-cell responses and survive indefinitely, but hearts transplanted into $\mathrm{Daf1}^{-/-} \mathrm{CD} \mathrm{O}^{-/-}$recipients undergo CD8 cell-dependent rejection. Together, the data indicate that heightened production and activation of immune cell-derived complement bypasses the need for CD40/CD154 interactions and implicate antigen-presenting cell-produced $\mathrm{C} 5 \mathrm{a}$ and $\mathrm{C} 3 \mathrm{a}$ as molecular bridges linking CD4 help to $\mathrm{CD8}^{+} \mathrm{T}$ cells. (Am J Pathol 2011, 179: 766-774; DOI: 10.1016/j.ajpath.2011.04.038)
\end{abstract}

Alloreactive $\mathrm{CD}^{+} \mathrm{T}$ cells that recognize donor class I major histocompatibility complex are the main effectors of transplant injury. ${ }^{1-5}$ Activation, differentiation, and expansion of naive $\mathrm{CD}^{+} \mathrm{T}$ cells into effector cells after transplantation requires T-cell receptor/class I major his- tocompatibility complex interactions in conjunction with helper signals provided by $\mathrm{CD}^{+}{ }^{+} \mathrm{T}$ cells. ${ }^{6}$ The importance of CD4 help is highlighted by findings in mice that CD4-cell depletion or genetic deficiency impairs the priming of donor-reactive $\mathrm{CD}^{+} \mathrm{T}$ cells and markedly prolongs cardiac allograft survival. ${ }^{6}$

The current concept about how CD4 cells provide help to alloreactive CD8 cells is that during cognate CD4 ${ }^{+}$T-cell/ antigen-presenting cell (APC) interactions, CD154 expressed on $\mathrm{CD}^{+}{ }^{+} \mathrm{T}$ cells transmits activating signals to APCs through ligation of APC CD40. ${ }^{7-9}$ This, in turn, upregulates APC costimulatory molecule (CD80/86) and major histocompatibility complex expression and induces pro-inflammatory cytokines (eg, IL-12), ${ }^{10}$ which promote CD8 ${ }^{+}$ T-cell activation, expansion, differentiation, and survival. These concepts are supported by findings in murine transplant experiments that survival of allogeneic heart grafts in $C D 40^{-\prime-}$ recipients is markedly prolonged ${ }^{11,12}$ and that cross-linking CD40 in CD4-deficient mice reconstitutes CD8-mediated allograft injury. ${ }^{13}$

Previous work by our joint group indicates that CD4 ${ }^{+}$ $\mathrm{T}$-cell/DC interactions induce local production of $\mathrm{C} 3 \mathrm{a}$ and $\mathrm{C} 5 \mathrm{a}$ which bind to $\mathrm{C} 3 \mathrm{a} / \mathrm{C} 5 \mathrm{a}$ receptors (C3aR, C5aR) on $\mathrm{T}$ cells, stimulating T-cell proliferation and survival. ${ }^{14-16}$ These published findings suggest that one molecular mechanism through which $\mathrm{CD}^{+}{ }^{+} \mathrm{T}$ cells might provide help in inducing an alloreactive $\mathrm{CD}^{+}{ }^{+}$-cell response to a transplant is through stimulating local $\mathrm{C} 3 \mathrm{a} / \mathrm{C5}$ a production by the APC, which then could activate the CD8 cells by ligating $\mathrm{C} 5 \mathrm{aR} / \mathrm{C} 3 \mathrm{aR}$ on their surfaces.

This hypothesis predicts that enhancing local complement activation could augment alloreactive $\mathrm{CD}^{+} \mathrm{T}$-cell responses, resulting in allograft rejection without CD4

Supported by National Institutes of Health grants R01 Al 071185 and Al/DK43578-05 (P.S.H.), a fellowship grant from the American Society of Transplantation (W.-H.K.), and a fellowship grant from the National Kidney Foundation (H.R.)

Accepted for publication April 12, 2011.

M.V. and S.L. contributed equally to this work.

Supplemental material for this article can be found at http://ajp. amjpathol.org or at doi: 10.1016/j.ajpath.2011.04.038.

Address reprint requests to Peter S. Heeger, M.D., Mount Sinai School of Medicine, Annenberg Bldg Box 1243, One Gustave L. Levy Place, New York, NY 10029. E-mail: peter.heeger@mssm.edu. 
help. To test this hypothesis, we performed in vitro studies and in vivo transplant experiments, including those with APCs devoid of decay accelerating factor (DAF; CD55), ${ }^{17}$ in which endogenous C3a/C5a production is tonically potentiated. ${ }^{14-16,18}$ We found that in the absence of either $\mathrm{CD} 4^{+} \mathrm{T}$ cells or APC CD40, heightened bone marrow (BM) cell-derived $\mathrm{C} 3 \mathrm{a} / \mathrm{C} 5 \mathrm{a}$ production provokes $\mathrm{CD} 8^{+} \mathrm{T}$-cell activation and cardiac allograft rejection. The findings show that one mechanism underlying CD4 help is that immune cell-derived complement functions as a molecular intermediary.

\section{Materials and Methods}

\section{Mice}

C57BL/6, B6.129S6-Cd4 $4^{\mathrm{tm} 1 \mathrm{knw} / \mathrm{J}}\left(\mathrm{CD}^{-1-}\right), \mathrm{C3}^{-/-}$, CD4O- ${ }^{-\prime-}, R_{A G 2^{-\prime-}}$, OTII (all $\left.H-2^{b}\right)$, as well as $C 3 a R^{-1-}$, mice (all $H-2^{d}$ ) were purchased from The Jackson Laboratory (Bar Harbor, ME). Factor $D\left(f D^{-/-}, H-2^{b}\right)$ mice were a gift from $Y$. Ma (Birmingham, AL). Mice deficient in the Daf1 gene $\left(\mathrm{Daf1}^{-{ }^{-}}\right)$were produced by Lin and colleagues ${ }^{17}$ as described and backcrossed for $>13$ generations to B6 mice. B6 mice do not reject B6 Daf1 ${ }^{-1-}$ skin (data not shown), confirming congenicity. $\mathrm{C} \mathrm{aR} \mathrm{R}^{-/-}$ mice $\left(H-2^{b}\right)$ were obtained from Craig Gerard (Boston, MA). Daf1 ${ }^{-\prime-}$ and $C 3^{-/-}$mice were each backcrossed for $>10$ generations to BALB/c to produce $\mathrm{H}-2^{d}$ Daf1 ${ }^{-/-}$ and $\mathrm{C}^{-{ }^{-\prime}}$ animals, respectively. $\mathrm{H}-2^{d} \mathrm{C} 3 a R^{-1-}$ mice were backcrossed $>9$ generations to $\mathrm{B} 6$ and then intercrossed with the $\mathrm{C}_{5} \mathrm{aR}^{-/-}$mice to produce $\mathrm{C}^{-} \mathrm{a} R^{-/-}$/ C5aR ${ }^{-/-}$mice $\left(H-2^{b}\right) . C D 4^{-1-} \mathrm{Daf1}^{-/-}, \mathrm{fD}^{-/-} \mathrm{Daf1} 1^{-/-}$, and $C D 40^{-1-}$ Daf1 ${ }^{-1-}$ mice $\left(H-2^{b}\right)$ were generated by, respectively, intercrossing the $C D 4^{-/-}, f D^{-1-}$, or the $\mathrm{CD} 4 \mathrm{O}^{-\prime-}$ mice with the Daf1 ${ }^{-\prime-}$ mice. All mice were housed in the Mount Sinai School of Medicine Center for Comparative Medicine and Surgery in accordance with guidelines of the Association for Assessment and Accreditation of Laboratory Animal Care International.

\section{Antibodies and Reagents}

All antibodies for flow cytometry were purchased from BD Pharmingen (San Diego, CA). Carboxy-fluorescein diacetate succinimydyl ester (CFSE) was obtained from Molecular Probes, Invitrogen (Carlsbad, CA). GK1.5 [depleting anti-CD4 monoclonal (mAb)] was purchased from BioXCell (West Lebanon, NH). Depleting anti-CD8 mAbs YTS169 and TIB105 were a kind gift from Robert Fairchild (Cleveland, OH). Depletion of CD4 (using GK1.5) cells was accomplished by i.p. administration of $100 \mu \mathrm{g}$ of antibody per mouse on days $-3,-2$, and 0 relative to the transplantation and weekly thereafter. Depletion of CD8 cells (using YTS169 and TIB105 administered together) was accomplished by i.p. administration of $100 \mu \mathrm{g}$ of each antibody per mouse on days $-3,-2$, and -1 relative to transplantation and every 5 days thereafter. The anti-CD4 (RM4-5) and anti-CD8 (53-6.7) mAbs used for flow cytometry (BD Pharmingen) were different clones from those used for depletion. Anti-CD40 mAb FGK45 and anti-CD154 mAb MR1 were purchased from BioXCell. Anti-DAF mAb 2C6 (produced in house) was used for phenotyping.

\section{BM Chimeras}

BM cells were collected from B6 $\left(\mathrm{C}^{+}\right) \mathrm{Daf1}^{-1-}$ or B6 $\mathrm{C}^{-/-}$mice. Recipient $\mathrm{B} 6 \mathrm{C}^{-/-}$or Daf1 ${ }^{-/-}$mice were irradiated with 6.5 Gy $(650 \mathrm{rad})$ then rested for 24 hours and irradiated with 6.0 Gy (600 rad) with the use of a Mark I Model 137Cs irradiator (JL Shepherd \& Associates, San Fernando, CA). Four hours after irradiation, recipient mice received $>8 \times 10^{6} \mathrm{BM}$ cells by retro-orbital injection. Chimerism of $>90 \%$ donor origin was confirmed at week 6 by staining for DAF expression on peripheral blood cells. The presence or absence of $\mathrm{C} 3$ in the serum was determined by C3 uptake on zymosan particles as described. ${ }^{16,19}$

\section{Surgical Procedures}

Heterotopic heart transplantation was performed as described. ${ }^{16,19,20}$ Heart graft function was monitored daily by palpation, and rejection was defined as the day on which a palpable heartbeat was no longer detectable. Formalinfixed paraffin sections of graft tissues were stained with H\&E and evaluated by a blinded investigator (P.S.H.). ${ }^{21}$

\section{Immunohistochemistry}

Sections (0.8- $\mu \mathrm{m}$ thick) of tissue frozen in OCT (Sakura Finetek, Torrance, CA) were fixed with acetone for $10 \mathrm{~min}$ utes, blocked with Avidin/Biotin blocking kit (Vector Laboratories, Burlingame, $\mathrm{CA}$ ) donkey serum $(5 \%)$, and then incubated with anti-CD4 mAb (clone RM 4-5; eBioscience, San Diego, CA), anti-CD8 mAb (clone 53-6-7; BD Biosciences, Franklin Lakes, $\mathrm{NJ}$ ), or an isotype control (BD Biosciences) for 1 hour. After washes in PBS, the slides were incubated with secondary biotinylated donkey anti-rat (Jackson ImmunoResearch Laboratories, West Grove PA) for 30 minutes, washed, and incubated with streptavidin horseradish peroxidase (BD) for 20 minutes, and developed with DAB+Nickel Kit (Vector Laboratories).

\section{In Vitro Cell Culture Assays}

$\mathrm{CD} 44^{\mathrm{lo}}, \mathrm{CD} 62 \mathrm{~L}^{\mathrm{hi}}, \mathrm{CD} 4$, and CD8 T-cell subsets were isolated by negative selection and $\mathrm{CD}_{11 \mathrm{c}^{+}}$splenic DCs by positive selection, using antibodies and magnetic beads obtained from StemCell Technologies (Vancouver, BC, Canada). Cells were labeled with CFSE (Molecular Probes, Invitrogen) as described. ${ }^{16,19}$ CFSE-labeled CD8 T cells $(400,000)$ with or without unlabeled CD4 cells $(25,000$ to 100,000$)$ were mixed with enriched 6000 to 25,0000 splenic DCs (positive selection; Stem Cell Technologies) in serum-free $\mathrm{HL}-1$ medium (BioWhittaker, Walkersville, MO) and incubated in 96-well flat-bottom plates for 4 days at $37^{\circ} \mathrm{C} 5 \% \mathrm{CO}_{2}$. The cells were washed and stained with anti-CD8, and CFSE dilution by flow cytometry was used as a measure of proliferation. Intracellular interferon (IFN)- $\gamma$ production was measured by standard techniques (antibodies and permeabilizing buf- 
fers from BD Biosciences). In selected assays the stimulator cells were labeled with CFSE which permitted gating on the non-labeled responder cells for flow cytometric readouts. Cells were stained for surface antigens by incubating with antibodies in PBS or a buffer consisting of $2 \%$ rat serum $2 \mathrm{mmol} / \mathrm{L}$ EDTA. Samples were collected with FACSCanto II (BD Biosciences) and analyzed with FlowJo software (TreeStar Inc., Ashland, OR).

\section{ELISPOT Assays}

Enzyme-linked immunospot (ELISPOT) assays were performed as previously described. ${ }^{12,16,17}$ Briefly, MultiScreen ELISPOT plates (Millipore, Bedford, MA) were coated overnight with the capture antibodies for IFN- $\gamma$, IL-4, or IL-17 (BD Biosciences). After a blocking step, recipient spleen or T cells $\left(0.2\right.$ to $1 \times 10^{6}$ per well) were plated and incubated with spleen cell stimulators $(400,000$ per well) at $37^{\circ} \mathrm{C}, 5 \% \mathrm{CO}_{2}$, for 24 hours. Donor spleen cell stimulators were treated with mitomycin $\mathrm{C}$ to limit proliferation and cytokine secretion. ${ }^{18}$ After washing, detection antibodies (BD Biosciences) were added overnight. After washing, alkaline phosphatase-conjugated anti-biotin antibody (Vector Laboratories) diluted 1:2000 in PBS Tween $1 \%$ bovine serum albumin was added for 90 minutes, the plates were developed, and the resulting spots were counted on an ImmunoSpot Series 4 Analyzer (Cellular Technology Ltd., Shaker Heights, $\mathrm{OH}$ ).

\section{Alloantibody Detection}

Diluted serum samples were incubated with syngeneic, donor, or third-party thymocytes as targets. ${ }^{19}$ After a wash step the bound antibody was detected with fluorescein isothiocyanate-conjugated rat anti-mouse IgG (eBioscience) and quantified by flow cytometry.

\section{C5a ELISA}

Splenic DCs were cultured in serum-free $\mathrm{HL}-1$ medium with either allogeneic or syngeneic splenic CD4 T cells, or OTII cells with ova $_{323-339}$, in 48-well plates with or without 4 $\mu \mathrm{g} / \mathrm{mL}$ anti-CD154 mAb MR1 or IgG isotype control for 48 to 72 hours. Culture supernatant fluids were concentrated with the use of Amicon Ultra-0.5, normal molecular weight limit of $10 \mathrm{kDa}$ (Millipore), and tested for C5a or C3a with Mouse Complement Component C5a or C3a Duo Set ELISA (enzyme-linked immunosorbent assay; R\&D Systems, Minneapolis, MN) as per manufacturer's instructions.

\section{Real-Time PCR}

RNA isolation was performed with Qiagen RNeasy Mini Kit (Qiagen, Inc., Valencia, CA), and cDNA was reversetranscribed with the use of the High-Capacity cDNA Reverse Transcription Kit (Applied Biosystems, Carlsbad, $\mathrm{CA}$ ) according to the manufacturer's instructions. PCR primers were purchased from TaqMan Gene Expression Assays (Applied Biosystems). Real-time PCR was performed with the Bio-Rad CFX96 Real-Time PCR Detection
System (Bio-Rad Laboratories, Inc., Hercules, CA). PCR products were normalized to the control gene and expressed as fold increase compared with unstimulated cells with the use of the $\Delta \Delta \mathrm{Ct}$ method. ${ }^{20}$

\section{Statistical Analysis}

Graft survival was compared with log-rank survival statistics. Immunology assay results were compared with the Student's $t$-test. $P<0.05$ was considered significant.

\section{Results}

\section{Cognate Interactions between $\mathrm{CD} 4^{+} \mathrm{T}$ Cells and Allogeneic DCs Yield C3a and C5a}

To test whether CD4 help and immune cell-derived complement are interconnected, we measured C3a and C5a in culture supernatant fluids of CD4 ${ }^{+}$OTII T cells mixed with syngeneic splenic DCs and ova $_{323-339}$ peptide in serum-free medium (Figure 1A). ELISAs showed the production of both anaphylatoxins. On the basis of this result together with previous work that implicated costimulatory molecule signaling as important inducers of DC complement production, ${ }^{14}$ we next asked how ligation of DCexpressed CD40 by CD4 ${ }^{+}$T cell-expressed CD154 affects immune cell C3a and C5a production. Blocking anti-CD154 mAb MR1 added to the OTII/DC culture prevented the production of both $\mathrm{C} 3 \mathrm{a}$ and $\mathrm{C} 5 \mathrm{a}$. When we mixed purified BALB/c CD4 ${ }^{+}$T cells with allogeneic C57BL/6 splenic DCs, we also detected $\mathrm{C} 5 \mathrm{a}$ in the culture supernatant fluids (Figure $1 \mathrm{~A}$ ), showing that alloreactions behave analogously to the T-cell receptor transgenic cells. In control experiments no C5a was detected in supernatant fluids of $\mathrm{CD}^{+}{ }^{+} \mathrm{T}$ cells incubated with syngeneic DCs.

To directly test the link between CD40 signaling and local complement production by APCs, we cross-linked CD40 on wild-type (WT) spleen cell APCs with the use of the agonist anti-CD40 mAb FGK45 and 24 hours later measured complement gene expression by real-time PCR. Levels of C3 and $\mathrm{fB}$ mRNA increased twofold to fivefold (Figure 1C). Control experiments with $C D 40^{-1-}$ APCs showed that antiCD40 mAb FGK45 did not increase C3 or fB mRNA expression, verifying the specificity of the above observations. RNA for C5 was detected in WT APCs, but its expression was not altered on CD40 cross-linking.

\section{In Vitro CD4 Help to Alloreactive CD8 T Cells Depends on C3a/C5a and Modulated by Immune Cell DAF}

As a test for whether immune cell-produced $\mathrm{C} 3 \mathrm{a} / \mathrm{C} 5 \mathrm{a}$ and CD4 help to alloreactive $\mathrm{CD}^{+}{ }^{+} \mathrm{T}$ cells are functionally linked, we purified naive CD44 ${ }^{\text {lo }}$ CD62 $L^{\text {hi }}$ splenic $\mathrm{CD}^{+} \mathrm{T}$ cells and tested their proliferation in response to allogeneic splenic DCs in the presence or absence of naive $\mathrm{CD}_{4} 4^{\mathrm{lo}} \mathrm{CD} 2 \mathrm{~L}^{\text {hi }} \mathrm{CD}^{+}{ }^{+} \mathrm{T}$ cells (as a source of CD4 help; Figure 1B). Although we observed weak $\mathrm{CD}^{+} \mathrm{T}$ cell proliferation in the absence of $\mathrm{CD} 4^{+}$cells, the addition of $\mathrm{CD}^{+}$cells enhanced the proliferation (Figure 1B). 
A
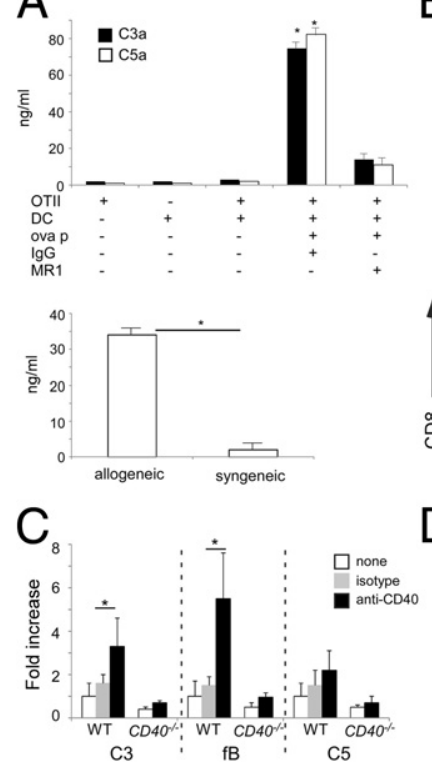

B

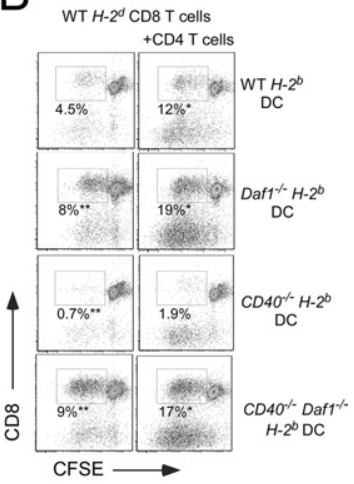

D

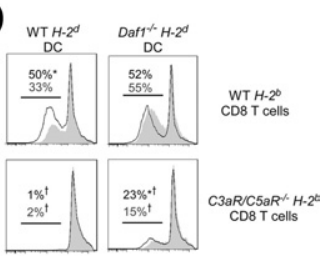

Figure 1. DAF-regulated, immune cell-derived complement transmits help to alloreactive CD8 T cells in vitro. A, top panel: C3a and C5a ELISA results performed on culture supernatant fluids of OTII cells mixed with B6 splenic DCs, ova ${ }_{323-339}$ plus MR1, or isotype control. ${ }^{*} P<0.05$ versus all other groups. Bottom panel: $\mathrm{B} 6 \mathrm{CD} 4$ cells mixed with allogeneic $\mathrm{BALB} / \mathrm{c}$ or syngeneic B6 DCs. ${ }^{*} P<0.05$. Results of triplicate wells are shown. B: Representative flow cytometric plots of flow cytometric plots of 4-day CFSE dilution proliferative assays with the use of $\mathrm{CD} 44^{\mathrm{lo}} \mathrm{CD} 62 \mathrm{~L}^{\text {hi }}$ splenic $H-2^{d} \mathrm{CD} 8$ $\mathrm{T}$ cells without (left panel) or with (right panel) $\mathrm{CD} 44^{\mathrm{lo}} \mathrm{CD} 62 \mathrm{~L}^{\mathrm{hi}} \mathrm{H}-2^{d} \mathrm{CD} 4$ T cells plus allogeneic $H-2^{b}$ DCs obtained from WT, Daf1 ${ }^{-1-}, C D 4 O^{-1-}$, or $C D 40^{-/ 1} / \mathrm{Daf1}^{-/-} .{ }^{*} P<0.05$ versus no CD 4 cells; ${ }^{* *} P<0.05$ versus WT CD8 $\mathrm{T}$ cells alone (upper left panel). C: Twenty-four-hour real-time PCR results for $\mathrm{C} 3, \mathrm{fB}$, and $\mathrm{C} 5$ gene expression obtained from unstimulated spleen cells or spleen cells stimulated with anti-CD 40 mAb FGK 45 (or an isotype control). Results of triplicate wells are shown. ${ }^{*} P<0.05$. Kinetic analysis showed no increase at 6 hours for any of the genes and similar fold increases at 48 hours compared with the data at 24 hours (not shown). D: Representative flow cytometric histograms gated on $\mathrm{CD}^{+}$cells from 4-day CFSE dilution proliferative assays with the use of $\mathrm{CD} 44^{\mathrm{lo}} \mathrm{CD} 62 \mathrm{~L}^{\text {hi }}$ splenic $H-2^{b}$ WT (top panel) or $\mathrm{CS}_{\mathrm{aR}}^{-/-} / \mathrm{C} \mathrm{aR} \mathrm{R}^{-/} \mathrm{CD} 8 \mathrm{~T}$ cells (bottom panel) with or without CD $44^{\text {lo }}$ CD $62 \mathrm{~L}^{\text {hi }}$ WT $H-2^{b}$ CD 4 T cells mixed with allogeneic $H-2^{d}$ DCs obtained from WT (left panel) or $\mathrm{Daf1}^{-/-}$(right panel) mice. Shaded areas in each panel depict responses without CD 4 cells, and solid black line histogram depicts CD8 responses in the presence of CD4 cells. The strain combinations are reversed compared with 1C. The 2 numbers in each panel are the mean percentages of the $\mathrm{CD}^{+} \mathrm{T}$ cells that have undergone at least two divisions (horizontal line) in the presence (upper number) or absence (lower number) of CD 4 cells for multiple replicates within that experiment. ${ }^{*} P<0.05$ versus no CD 4 cells; ${ }^{\dagger} P<0.05$ versus WT CD8 T cells + WT or Daf1 $1^{-1-}$ DCs \pm CD 4 and versus C3aR/C5aR ${ }^{-1}$ CD8 T cells + Daf1 $^{-/}$DCs \pm CD 4 ; and $\dagger P<0.05$ versus WT CD8 T cells + WT or Daf1 ${ }^{-\prime}$ DCs \pm CD 4 and versus WT CD8 T cells + Daf1 $1^{-1-}$ DCs \pm CD4. Each experiment was repeated at least twice with the same results.

To test whether augmenting DC C3a/C5a in the absence of CD4 cells increases allogeneic $\mathrm{CD}^{+}{ }^{+} \mathrm{T}$-cell responses, we mixed the $\mathrm{CD}^{+} \mathrm{T}$ cells with allogeneic Daf1 ${ }^{-1-}$ DCs (Figure 1, B and D). DAF deficiency lifts restraint on local complement activation, yielding enhanced production of $\mathrm{C} 3 \mathrm{a}$ and $\mathrm{C} 5 \mathrm{a} .{ }^{14,15}$ Significantly more CD8 cell proliferation occurred under these conditions ( $P<0.05$ versus WT DCs). Addition of CD4 ${ }^{+}$T cells to these cultures further increased $\mathrm{CD}^{+} \mathrm{T}$-cell proliferation (Figure 1B; $P<0.05$ versus WT \pm CD4 cells).

In accordance with CD40 costimulation being required for CD4 help, we found that naive $\mathrm{CD}^{+} \mathrm{T}$ cells did not proliferate when mixed with allogeneic $C D 40^{-1-} \mathrm{DCs}$, irrespective of the addition of $\mathrm{CD}^{+} \mathrm{T}$ cells (Figure 1B).
However, when we cultured WT CD8 ${ }^{+} \mathrm{T}$ cells with allogeneic DCs from Daf1 ${ }^{-1-} \mathrm{CD} 40^{-1-}$ animals (conditions of amplified C3a/C5a production), we observed strong proliferation without $\mathrm{CD} 4^{+} \mathrm{T}$ cells.

Because our previous studies indicated that C3aR/ C5aR signaling in $\mathrm{T}$ cells promotes proliferation, ${ }^{15}$ we next tested whether the CD4 help depended on CD8 ${ }^{+}$ T-cell C3aR/C5aR signaling (Figure 1D). In contrast to the WT CD8 T-cell responses (Figure 1, B and D), when we

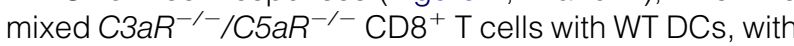
or without $\mathrm{CD}^{+}$cells, we observed that no proliferation occurred. These in vitro findings, performed in the absence of exogenous (systemic) complement, argue that under physiological conditions CD4 help is transmitted to alloreactive $\mathrm{CD}^{+}$cells by DC-generated C3a/C5a which signals through $\mathrm{CD}^{+} \mathrm{T}$ cell-expressed $\mathrm{C} 3 \mathrm{aR} / \mathrm{C} 5 \mathrm{aR}$.

When we mixed $\mathrm{C} 3 \mathrm{a} R^{-1-} / \mathrm{C} \mathrm{a} \mathrm{R}^{-1-} \mathrm{CD} 8^{+} \mathrm{T}$ cells with allogeneic Daf1-/- DCs (Figure 1D, lower right), we observed weak proliferation that was modestly enhanced by the addition of CD4 cells. These responses were significantly lower than those of WT CD8 T cells mixed with Daf1 $^{-1-}$ DCs (Figure 1D, upper right; $P<0.05$ ). That ${\mathrm{C} 3 a R^{-1-} / \mathrm{C} 5 \mathrm{aR}}^{-1-} \mathrm{CD}^{+} \mathrm{T}$ cells responded to Daf1 ${ }^{-1-}$ (but not WT) DCs indicates that, when complement activation is heightened, the locally produced complement can stimulate CD8 cells by other mechanisms (in addition to direct transmission of CD8 T-cell C3aR/C5aR signals).

\section{Augmented DC C3a/C5a Production Bypasses the Need for CD4 Help to Reject a Heart} Transplant

To test the relationship between complement activation and T-cell help in vivo, we used a cardiac allograft rejection model that depends on CD4 help. We determined whether DAF deficiency, through enhancing local complement activation, would bypass the need for CD4 cells to reject an allograft. We transplanted BALB/c heart grafts into allogeneic WT or Daf1 ${ }^{-1-}$ B6 mice depleted of $\mathrm{CD} 4^{+}$cells. We found that, although hearts transplanted into CD4-depleted WT mice survived for $>58$ days, compared with 7 to 9 days in $\mathrm{CD}^{+}{ }^{+}$cell-sufficient WT mice, hearts transplanted into CD4-depleted Daf1 ${ }^{-1-}$ mice had a median survival time of 23 days $(P<0.05$; Figure $2 A)$. At the time of rejection $\mathrm{CD} 4^{+} \mathrm{T}$ cells were not detectable in any of the CD4-depleted recipients (Figure 2B), confirming that the CD4 depletion protocol was effective. Control experiments documented that non-CD4-depleted Daf1 ${ }^{-1-}$ mice rapidly rejected $\mathrm{BALB} / \mathrm{c}$ heart grafts (Figure 2A).

When we examined the histology of the heart grafts rejected by CD4-depleted Daf1 ${ }^{-1-}$ mice, we found diffuse mononuclear cell infiltrates typical of acute cellular rejection, without histologic evidence of vasculitis (Figure 3A). Immunohistochemical analysis of the rejected graft tissue showed CD8 but not CD4 staining (Figure 3B), unlike rejected allografts from untreated WT mice which stained positive for CD4 and CD8.

To formally test whether the accelerated graft rejection in CD4 cell-depleted Daf1 ${ }^{-/-}$mice occurred by a 

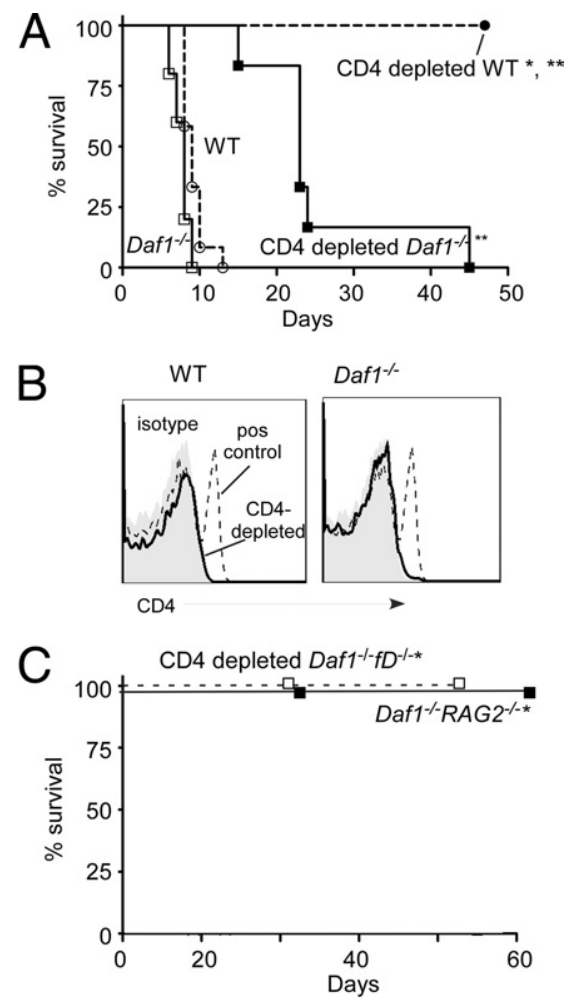

Figure 2. Recipient Daf1 deficiency results in cardiac allograft rejection despite CD 4 depletion. A: Survival of BALB/c hearts transplanted into B6 WT $(n=12), \operatorname{Daf1}^{-/}(n=5)$, CD4-depleted WT $(n=5)$, or CD4depleted $\mathrm{Daf1}^{-/-}(n=6)$. B: Representative flow plots of CD4 staining performed on spleens cells obtained from CD4-depleted WT (left, day 50 after transplantation) or $\mathrm{Daf1}^{-/-}$(right, at rejection) recipients. Black line indicates experimental animal; dashed line, positive control spleen from a naive WT B6 mouse; and gray area, isotype control. No CD4 staining above background was detected in any of the CD4-depleted animals. C: Survival of BALB/c hearts transplanted into CD4-depleted $f D^{-/-} / \mathrm{Daf1} 1^{-/-}$or $\mathrm{Daf1} 1^{-/-} / R A G 2^{-/-}$recipients ( $n=5$ per group). BALB/c hearts also survived $>60$ days in CD4-depleted $f D^{--}$mice, $n=$ 4 , not shown. ${ }^{*} P<0.05$ versus CD4-depleted Daf1 $^{-/-}$; *** $P<0.05$ versus WT controls.

complement-dependent process, we performed an identical experiment in Daf1 ${ }^{-/-} f D^{-/-}$mice (Figure 2C). In contrast to rejection observed in CD4-depleted Daf1 ${ }^{-1-}$ mice (median survival time, 23 days), allografts transplanted into CD4-depleted Daf1 ${ }^{-/-} f D^{-1-}$ mice (and in CD4-depleted $f D^{-/-}$recipient controls) survived for $>50$ days.

To verify that graft rejection was mediated by $\mathrm{CD}^{+}$ $T$ cells and to exclude an effect of serum complement as an effector of graft injury, we transplanted BALB/C hearts into congenic B6 mice deficient in both Daf1 and RAG2. Grafts survived $>65$ days in Daf1 ${ }^{-1-} / R_{A G} 2^{-1-}$ recipients ( $n=5$; Figure $2 \mathrm{C}$ ), and histologic analyses of hearts harvested on day 90 after transplantation showed no evidence of vasculopathy (Figure 3C).

\section{Heightened C3a/C5a Production Facilitates CD8 ${ }^{+}$ T-Cell Priming in the Absence of CD4 Cells}

To assess the effect of DAF deficiency (which heightens $\mathrm{C} 3 \mathrm{a} / \mathrm{C} 5 \mathrm{a}$ production) on priming of donor-reactive cellular immunity in the absence of $\mathrm{CD}^{+}{ }^{+} \mathrm{T}$ cells, we repeated the above transplantations this time quantifying donor-reactive IFN- $\gamma$-producing cells in spleens 2 weeks after transplantation (Figure 4A). This analysis showed higher frequencies and higher absolute numbers of splenic IFN- $\gamma$ producers in CD4-depleted Daf1 ${ }^{-/-}$recipients than in CD4-depleted WT controls. Fewer than 10 IFN- $\gamma$ producers per 400,000 cells were present in the spleens of naive CD4-depleted WT and Daf1 ${ }^{-1-}$ mice (not shown), indicating that detected responses were induced by the transplant and were not an unanticipated effect of DAF deficiency per se. IL-4 and IL-17 ELISPOT assays showed no differences in the frequencies of IL-4 and IL-17 producers in WT and Daf1 $^{-1-}$ recipients of heart grafts (Figure $4 \mathrm{~B}$ ), consistent with the dominant effect of DAF deficiency in transplant rejection being to augment type 1 CD8 alloimmunity.

To determine whether alloantibody responses and consequent activation of systemic complement contribute to the accelerated rejection in the absence of CD4 ${ }^{+}$ cells, we tested sera from each recipient for anti-class I, $H-2^{d}$-reactive IgG (Figure $4 \mathrm{C}$ ). Although this analysis showed strong anti-donor IgG from sera obtained from WT recipients that rejected hearts, no anti-donor IgG was detectable in any of the CD4-depleted, WT, or Daf1 ${ }^{-1-}$ animals at 3 weeks after transplantation (the time of rejection for the Daf1 ${ }^{-/-}$recipients).

As an independent way to test the role of immune cell-produced complement in CD4 help, we performed experiments with mice genetically deficient in $\mathrm{CD}^{+}$ cells. We transplanted BALB/C hearts into B6 $\mathrm{CD} 4^{-/-}$ recipients and into Daf1 ${ }^{-/-} / C D 4^{-/-}$mice. Consistent with the literature, ${ }^{6}$ we found that $90 \%$ of grafts transplanted into $C D 4^{-1-}$ recipients exhibited prolonged survival (Figure 5A). In contrast, $60 \%$ of grafts transplanted into Daf1 ${ }^{-/-} / C D 4^{-/-}$recipients were rejected by day 40 (Figure $5 \mathrm{~A} ; P<0.05$ versus $C D 4^{-1-}$ recipients). Recall assays with the use of purified splenic $\mathrm{CD}^{+} \mathrm{T}$ cells isolated on day 14 after transplantation showed higher frequencies of donor-reactive IFN- $\gamma$ producers in the $D a f 1^{-/-} / C D 4^{-/-}$mice than in the $C D 4^{-1-}$ recipients (Figure $5 \mathrm{~B}$ ). No anti-donor IgG alloantibodies were detectable in the sera from mice of either group (not shown).

\section{BM Cell-Derived C3 and Daf1 Regulate CD4-Independent Graft Rejection}

Previous work with BM chimeras by our joint group showed that T-cell immunity depends on immune cellderived complement regulated by immune cell-expressed DAF, rather than serum complement. ${ }^{14-16}$ To distinguish whether CD8 cell-mediated heart graft rejection in the absence of CD4 cells similarly depends on immune cell complement, we transplanted BM cells from Daf1 ${ }^{-/-}$mice (which are $\mathrm{C}^{+}$) into $\mathrm{C3}^{-1-}$ recipients $\left(\right.$ Daf1 $^{-1-} \mathrm{BM} \rightarrow \mathrm{C}^{-1-} ;$ Figure $\left.6 \mathrm{~A}\right)$. In these chimeras, C3 can only be produced by the Daf1 ${ }^{-1-}$ BM cells (no systemic/serum C3). We also prepared $\mathrm{C}^{-/-} \mathrm{BM} \rightarrow \mathrm{Daf1}^{-/-}$ chimeras in which systemic/serum $\mathrm{C} 3$ is normal, but BM 
A
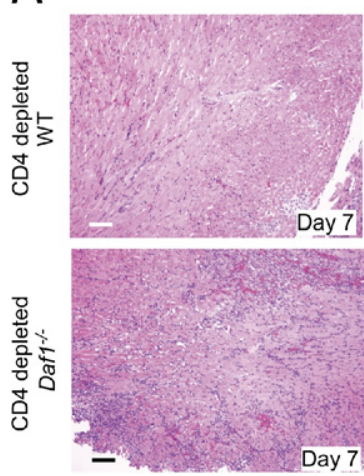

B
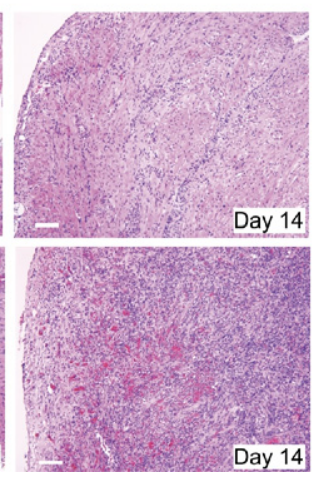

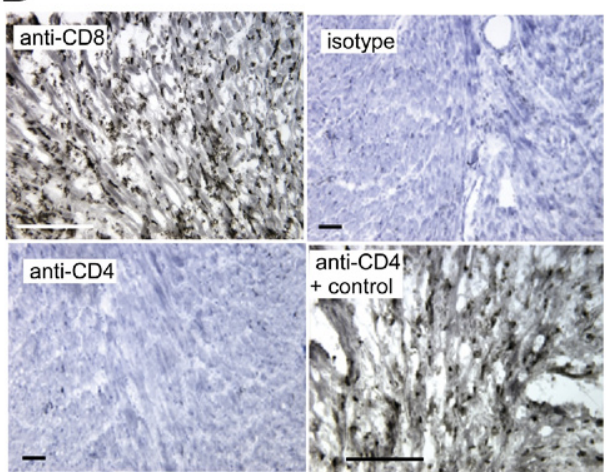

C RAG2 $\%$ Daf1 $\%$

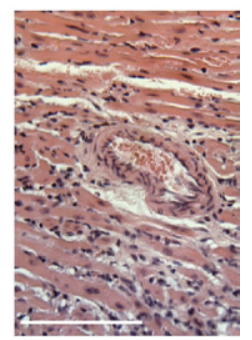

Figure 3. Graft histology in CD4-depleted Daf1 $1^{-/}$mice shows cellular rejection and CD8-cell infiltration. A: Photomicrographs of H\&E-stained heart graft tissue obtained from CD4-depleted WT or Daf $1^{-1-}$ recipients on day 7 or 14 after transplantation. Representative of three to five grafts per group. B: Immunohistochemical staining with anti-CD8 (upper left panel), isotype control (upper right panel), or anti-CD4 (lower two panels) of BALB/c heart graft tissue obtained from a CD4-depleted $D a f 1^{-/-}$recipient (left two panels and upper right panel) or from a non-depleted WT B6 recipient (lower right panel) at the time of rejection. C: Photomicrograph of H\&E-stained heart graft tissue obtained from a Daf $1^{-/-} / R A G 2^{-/-}$recipient on day 65 after transplantation showing a normal artery without vasculopathy and no mononuclear cell infiltration. Representative of more than three stained sections from each of 3 or more animals per group. Scale bars: $10 \mu \mathrm{m}(\mathbf{A}-\mathbf{C})$.

cells cannot produce C3. Flow cytometry 8 weeks later verified that all peripheral blood cells from the Daf1 ${ }^{-1-}$ $\mathrm{BM} \rightarrow \mathrm{C}^{-1-}$ chimeras were devoid of cell surface DAF, whereas all from the $\mathrm{C} 3^{-/-} \mathrm{BM} \rightarrow$ Daf1 $^{-/-}$chimeras expressed DAF on their surfaces (Figure 6B, top). C3 uptake assays confirmed the absence of serum C3 in the $\mathrm{C}^{-1-}$ recipients of $\mathrm{Daf1}^{-1-} \mathrm{BM}$ and the presence of $\mathrm{C} 3$ in the Daf1 ${ }^{-1-}$ recipients of $C 3^{-/-}$BM (not shown). After CD4 depletion of each chimeric group, we transplanted each with allogeneic BALB/c hearts. Hearts transplanted into Daf1 ${ }^{-/-} \mathrm{BM} \rightarrow \mathrm{C}^{-/-}$chimeras (C3 produced only by $\mathrm{BM}$ cells) rejected with a median survival time of 20 days, and recipient spleens contained high frequen-
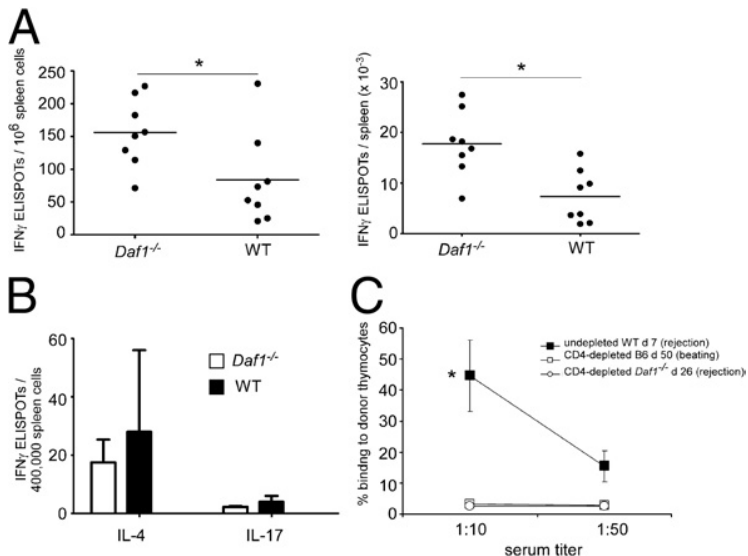

Figure 4. Daf1 deficiency augments IFN- $\gamma$-producing T-cell alloimmunity without anti-donor IgG antibody in CD4-depleted recipients. A: Frequency (left panel) and absolute number (right panel) of donor-reactive IFN- $\gamma$ producers in spleens of CD4-depleted allograft recipients studied on day 14 after transplantation as measured by ELISPOT. In non-depleted WT recipients of BALB/c hearts, the frequency of donor reactive IFN- $\gamma$ producers in the spleen at the time of rejection (days 7 to 9 ) is $>1500$ per million (not shown). B: Frequency of donor-reactive IL- 4 and IL-17 producers in spleens of CD4depleted allograft recipients studied on day 14 after transplantation as measured by ELISPOT ( $n=2$ to 4 per group; $P=$ NS between WT and Daf $1^{- \text {- }}$ recipients for both cytokines). C: Anti-donor IgG in sera obtained from un-depleted WT, CD4-depleted WT, or CD4-depleted Daf1 ${ }^{-/-}$recipients of $\mathrm{BALB} / \mathrm{c}$ heart grafts $\left(n=4\right.$ to 6 per group). ${ }^{*} P<0.05$. cies of donor-reactive IFN- $\gamma$ producers (Figure 6, C and $\mathrm{D})$. In contrast, all hearts transplanted into the $\mathrm{C}^{-1-} \mathrm{BM} \rightarrow \mathrm{Daf1}^{-1-}$ chimeras continued to beat beyond 60 days, and recipient spleens (obtained on day $60)$ contained low or undetectable numbers of donorreactive IFN- $\gamma$ producers (Figure 6, C and D). As in previous experiments, none of the CD4-depleted animals that received transplants produced detectable donor-reactive IgG alloantibodies (data not shown). In control experiments, allografts transplanted into CD4depleted, WT BM $\rightarrow$ WT chimeras survived $>60$ days. These results are consistent with the interpretation that rejection in the absence of $\mathrm{CD}^{+}{ }^{+}$cells is linked to $\mathrm{C} 3$ activated on BM-derived cells.

\section{Heightened C3a/C5a Production Bypasses the Requirement for CD40 in Cardiac Allograft Rejection}

Together, the results thus far indicate that potentiated C3a/C5a production by BM-derived cells bypasses the requirement for CD4 help for CD8-mediated rejection of a heart allograft. The in vitro results (Figure 1) taken to-
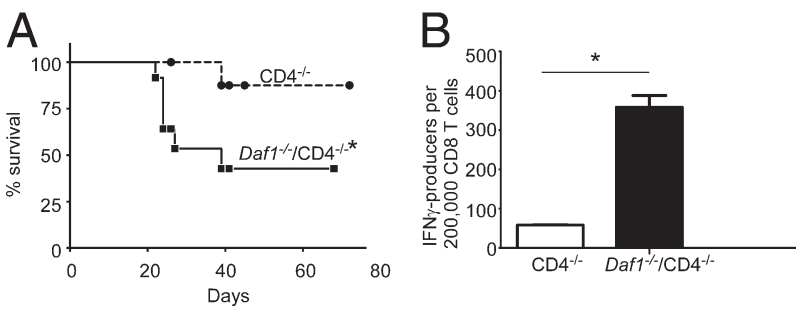

Figure 5. Recipient Daf1 deficiency results in cardiac allograft rejection and enhanced T-cell priming in $C D 4^{-/-}$recipients. A: Survival of BALB/c hearts transplanted into $\mathrm{B} 6 \mathrm{CD}^{-/-}$or $\mathrm{B} 6 \mathrm{Daf1}^{-/-} \mathrm{CD} 4^{-/-}$recipients $(n=6$ to 8 per group). ${ }^{*} P<0.05$ versus $C D 4^{-1-}$ by log-rank test. B: Frequency of IFN- $\gamma$-producing, donor-reactive, enriched splenic T cells $\left(\sim 70 \% \mathrm{CD}^{+}, 0 \%\right.$ $\left.\mathrm{CD}^{+}\right)$pooled from groups of $\mathrm{B} 6 \mathrm{CD}^{-1-}$ or $\mathrm{B} 6 \mathrm{Daf1}^{-1-} \mathrm{CD} 4^{-/}$recipients of BALB/c hearts (pooled from four animals per group) studied on day 14 after transplantation as measured by ELISPOT. ${ }^{*} P<0.05$. 


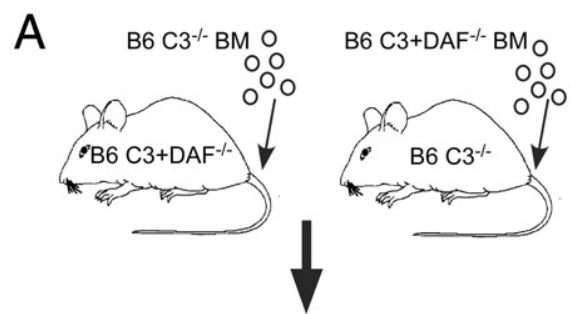

8 weeks, verify phenotype

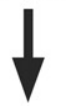

CD4 depletion

Transplant with BALB/c heart

B
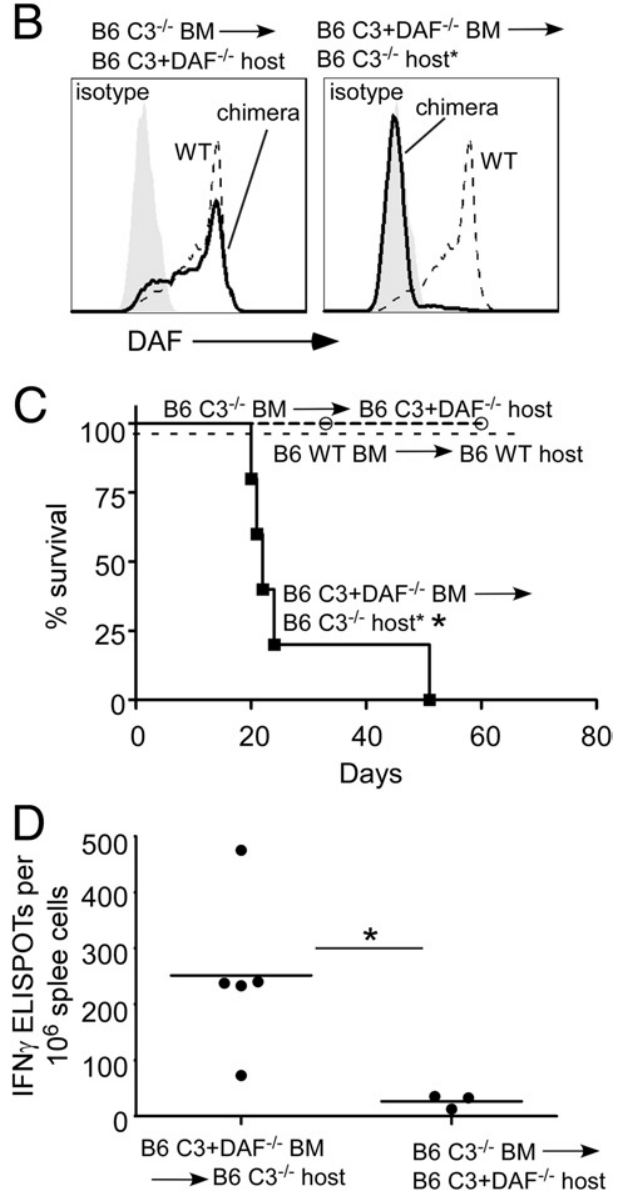

Figure 6. Recipient Daf1 deficiency on BM cells results in cardiac allograft rejection despite CD4 depletion. A: Schematic representation of experimental strategy. B: Validation of chimeras. Peripheral blood mononuclear cells were obtained 8 weeks after BM transplantation and stained for DAF expression (solid black lines). Isotype control (gray). C: Survival of BALB/c hearts transplanted into CD4-depleted chimeric B6 recipients $(n=4$ to 6 per group). D: Frequency of donor-reactive IFN- $\gamma$ producers in spleens of CD4-depleted chimeric allograft recipients studied at the time of rejection or on day 60 after transplantation as measured by ELISPOT. No anti-donor IgG was detected in sera obtained from the chimeric recipients (not shown). ${ }^{*} P<0.05$.

gether with the in vivo studies in BM chimeras (Figure 6) suggest that heightened $\mathrm{C} 3 \mathrm{a} / \mathrm{C} 5 \mathrm{a}$ production that is immune cell derived can substitute for CD40/CD154 interactions in murine heart graft rejection. To test this, we transplanted hearts into $C D 40^{-1-} / \mathrm{Daf1}^{-1-}$ mice and
$\mathrm{CD} 40^{-1-}$ mice as controls (without CD4 depletion; Figure 7). Consistent with heightened APC C3a/C5a production overcoming the absence of CD154/CD40 interaction connected with help, hearts transplanted into $C D 40^{-1-}$ / Daf1 ${ }^{-1-}$ animals were rapidly rejected (by day 20; Figure 7A). Allografts transplanted into control $C D 40^{-1-}$ mice continued to beat beyond 70 days $(P<0.05)$.

In accordance with the survival data, diffuse mononuclear cell infiltration was present in hearts rejected in $\mathrm{CD} 40^{-1-} /$ Daf1 $^{-1-}$ mice, whereas hearts in $\mathrm{CD} 40^{-1-}$ recipients exhibited minimal infiltration (Figure 7B). Intracellular staining of $\mathrm{CD}^{+}$and $\mathrm{CD}^{+}{ }^{+}$T cells for IFN- $\gamma$ in spleens taken 9 days after additional sets of transplants showed twofold more donor-reactive CD8 cells in the $\mathrm{CD} 40^{-1-} / \mathrm{Daf1}^{-1-}$ recipients than in the $\mathrm{CD} 40^{-1-}$ recipients (Figure 7, C and D). In control experiments we observed robust donor-reactive CD8 cell-derived IFN- $\gamma$ responses in WT animals that rejected their allografts by day 9 and essentially no responses in naive mice. No anti-donor alloantibody was detectable in the sera obtained from either the $C D 40^{-1-} / \mathrm{Daf1}^{-1-}$ or $C D 40^{-/-}$re-

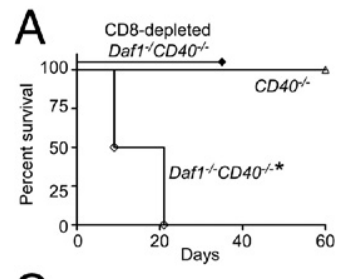

B

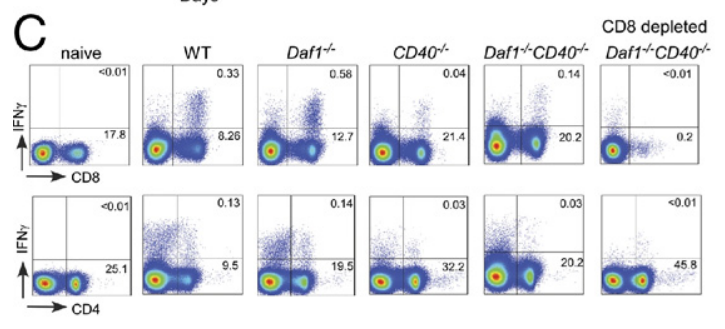

D

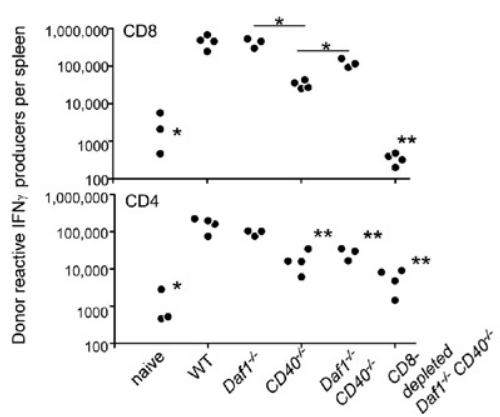

Figure 7. Recipient Daf1 deficiency results in cardiac allograft rejection and enhanced T-cell priming in $C D 40^{-1-}$ mice A: Survival of BALB/c hearts transplanted into $C D 40^{-/-}$or $\operatorname{Daf1}^{-/-} C D 4 O^{-/-}$recipients $(n=4$ to 6 per group). ${ }^{*} P<0.05$ versus both other groups. B: Representative H\&E-stained section of a rejected $\mathrm{BALB} / \mathrm{C}$ heart graft in a $\mathrm{Daf1} 1^{-/} \mathrm{CD}_{4} \mathrm{O}^{-/-}$recipient (right) and of a beating $\mathrm{BALB} / \mathrm{c}$ heart graft in a $C D 40^{-/-}$recipient (day 60, left). C: Frequency of donor-reactive CD8 (top) and CD4 (bottom) IFN- $\gamma$ producers as measured by flow cytometry in spleens of allograft recipients studied on days 8 to 9 after transplantation for all groups except the CD8depleted $\mathrm{Daf1} 1^{-/-} \mathrm{CD} 4 \mathrm{O}^{-/-}$mice (day 35 after transplantation). Numbers are percentages in each quadrant (representative of an individual experiment). D: Quantification of the total number of splenic IFN- $\gamma$-producing alloreactive CD8 and CD 4 T cells in each mouse (percentage of IFN- $\gamma$ producers $\times$ number of spleen cells) for each group. ${ }^{*} P<0.05$, **** $P<0.05$ between the noted groups in the top panel (CD8) and versus WT control in the bottom panel (CD4). Scale bar $=10 \mu \mathrm{m}(\mathbf{B})$. 
cipients (not shown). Transplantation of BALB/c hearts into CD8-depleted $\mathrm{CD} 4 \mathrm{O}^{-/-} / \mathrm{Daf1}^{-/-}$mice resulted in prolonged graft survival and an absence of anti-donor IFN- $\gamma$ producers in spleens (Figure 7), in contrast to the rejection noted by day 20 in untreated $C D 40^{-/-} / D_{\text {aff }}{ }^{-/-}$recipients.

\section{Discussion}

The findings in this study indicate that one mechanism through which CD4 cells "license" $\mathrm{APCs}^{8,9}$ to activate $\mathrm{CD}^{+} \mathrm{T}$ cells is through heightened APC production of $\mathrm{C} 3 \mathrm{a} / \mathrm{C} 5 \mathrm{a}$. In vitro, cognate CD4/APC interactions induced $\mathrm{C} 3 \mathrm{a} / \mathrm{C} 5 \mathrm{C}$ release through a CD40/CD154-dependent mechanism. Daf1 deficiency, which lifts restraint on $\mathrm{C} 3 \mathrm{a} / \mathrm{C} 5 \mathrm{a}$ generation, bypassed the need for CD4 help and bypassed the requirement for CD40/ CD154 interactions to induce CD8 T-cell alloresponses (Figure 1). C5aR ${ }^{-/-} / \mathrm{C}_{3} a R^{-/-} \mathrm{CD} 8 \mathrm{~T}$ cells did not respond to allogeneic WT DCs regardless of the presence of CD4 cells (Figure 1), indicating that physiologically CD4 help to CD8 T cells is at least partially mediated by $\mathrm{C} 3 \mathrm{a} / \mathrm{C} 5 \mathrm{a}$ signaling through $\mathrm{C} 3 \mathrm{aR} / \mathrm{C} 5 \mathrm{aR}$ expressed on CD8 cells.

In vivo, we found that Daf1 ${ }^{-/-}$mice depleted of CD4 cells, either immunologically or genetically, reject cardiac allografts faster than CD4-deficient WT animals (Figures 1 and 4). Graft tissue stained positive for CD8 but not CD4 cells, graft histology showed mononuclear infiltrates indicative of rejection, and serum analyses showed no IgG alloantibodies (Figures 2-4). Transplantations performed in Daf1 ${ }^{-\prime-}$ RAG2 $^{-\prime-}$ mice showed that this CD4independent allograft rejection required $T$ cells (Figure 2), arguing against a direct effect of heightened systemic complement activation as a mediator of graft injury. Transplantations performed in $D a f 1^{-/-} f D^{-/-}$mice showed that the rejection required fD (Figure 2), indicating that it occurred through an alternative pathway, complement-dependent mechanism.

Transplantations performed in BM chimeric recipients showed that the CD4-independent rejection occurred when BM-derived cells generated increased $\mathrm{C} 3 \mathrm{a} / \mathrm{C} 5 \mathrm{a}$ (Figure 6). This interpretation was confirmed by findings that accelerated rejection did not occur in the DAF-deficient hosts with $\mathrm{C3}^{-1-} \mathrm{BM}$, despite the presence of serum C3 (Figure 6). Although it is theoretically possible that BM-derived C3 could activate systemically in the Daf1 ${ }^{-1-} \mathrm{BM} \rightarrow \mathrm{C3}^{-/-}$chimeras and thereby influence Tcell activation indirectly, ${ }^{22}$ serum $\mathrm{C} 3$ was undetectable by C3 uptake on zymosan particles. In addition, the in vitro experiments performed in the absence of serum showed that T-cell help is modulated by immune cellderived C3a/C5a (Figure 1), lending further support to the interpretation that CD4 help relies on immune cell-derived, but not systemic, complement.

Consistent with the above interpretation, our data showed that lifting restraint on $\mathrm{C} 3 \mathrm{a} / \mathrm{C} 5 \mathrm{a}$ production (in the absence of DAF) is sufficient to overcome the need for CD40/CD154 signaling to prime alloreactive $\mathrm{CD}^{+} \mathrm{T}^{+}$ cells, which mediate rejection. Interestingly, examination of graft histology on day 30 after transplantation in the
CD8-depleted Daf1 ${ }^{-1-} \mathrm{CD} 40^{-1-}$ recipients showed mononuclear cell infiltration despite a palpable heartbeat (see Supplemental Figure S1 at http://ajp.amjpathol.org). This latter observation raises the possibility that CD4 cells can mediate injury despite CD40 deficiency when restraint on complement activation is lifted, an issue that will require further investigation.

The molecular basis for these observations has been elucidated in part through our previous work. ${ }^{14-16,19,20,23}$ We showed that cognate interactions between $\mathrm{CD} 4^{+} \mathrm{T}$ cells and APCs up-regulate synthesis of $C 3, f B$, fD, and C5 and down-regulate expression of cell surface DAF, together result in the local production of $\mathrm{C} 3 \mathrm{a}$ and $\mathrm{C} 5 \mathrm{a}$. Daf1 ${ }^{-1-}$ APCs produce more C3a/C5a because restraint on complement activation is tonically lifted. ${ }^{14,15,19}$ On binding to their $G$ protein-coupled receptors expressed on APCs, we showed that the locally produced $\mathrm{C} 3 \mathrm{a}$ and C5a up-regulate APC CD80/86 expression and augment IL-12 production (among other cytokines), which have been shown by others to enhance CD8 T-cell reactivity. $^{8-10}$ Such complement-dependent APC activation could contribute to the CD8 T-cell expansion that we observed in CD4-deficient, Daf1 ${ }^{-1-}$ heart graft recipients (Figures 3, 5, and 6) and provides an explanation for the proliferative response of $\mathrm{C} 3 \mathrm{aR} / \mathrm{C} 5 \mathrm{a} R^{-/-} \mathrm{T}$ cells to allogeneic Daf1-/- APCs (Figure 1D).

Our previous work also showed that immune cell-produced $\mathrm{C} 5 \mathrm{a} / \mathrm{C} 3 \mathrm{a}$ bind to their receptors on the T cells and, through phopho-inositol-3 kinase $\gamma / \mathrm{AKT}$ signals, ${ }^{14,15}$ directly stimulate proliferation and inhibit apoptosis, the latter through up-regulating $\mathrm{Bcl}-2$ and down-regulating Fas. ${ }^{15}$ The absence of C3aR/C5aR signal transduction dramatically diminishes APC activation and limits functional T-cell priming in vivo, preventing protective immunity to toxoplasmosis ${ }^{14}$ and abrogating the clinical and histologic manifestations of autoimmune encephalomyelitis. ${ }^{23}$ Together with this body of work our new data not only support the concept that CD4 help to CD8 cells occurs through CD40-induced "licensing" of APCs (which leads to up-regulation of CD86 and production of IL-12) but also indicate that immune cellproduced $\mathrm{C} 3 \mathrm{a}$ and $\mathrm{C} 5 \mathrm{a}$ are intermediaries. It is notable that CD40-expressing, $\mathrm{C}^{-/-}$mice can reject allografts, but the induced T-cell responses are significantly weaker than in WT recipients. ${ }^{24}$ Similarly, antiviral CD8 cell responses are suboptimal in $\mathrm{C}^{-1-}$ and $\mathrm{C} 5 \mathrm{a} R^{-1-}$ mice. ${ }^{25-27}$ Together with our new data these published findings support the concept that local complement production links CD40-transmitted signals to APC activation but also suggest that complement-independent mechanisms contribute to CD40-induced, APC activation.

Although we showed that recipient Daf1 deficiency facilitated CD8 T-cell priming and graft rejection independent of CD4 cells or CD40, Daf1 deficiency did not induce alloantibody isotype switching in the absence of either CD4 or CD40. Signaling pathways transmitted by CD154/CD40 on $B$ cells which induce isotype switching differ from those that activate DCs, ${ }^{28-31}$ providing a molecular basis for the complement dependence in one case but not the other. 
In addition to providing fundamental information on how complement affects CD8 T-cell responses in vivo, our results have clinical implications. They raise the possibility that complement blockade could be used to block CD4 help and, as a result, inhibit CD8 cell priming and thereby prevent/delay rejection of class I major histocompatibility complex disparate allografts. Conversely, blocking or removing immune cell DAF theoretically could be exploited to enhance local complement activation and expand CD8 cells in response to a pathogen, ${ }^{27}$ a strategy that might be particularly relevant to enhancing inadequate T-cell responses associated with certain chronic infections. $^{32}$

\section{Acknowledgments}

We thank Yansui Li, Peter Boros, and Jonathan Bromberg for their assistance with murine heart transplant surgery and Denise Peace, Ghazaul Dezfuli, Parth Lakhani, and Evita Scott for their assistance with producing and maintaining the animal colonies.

\section{References}

1. Rosenberg AS, Munitz TI, Maniero TG, Singer A: Cellular basis of skin allograft rejection across a class I major histocompatibility barrier in mice depleted of CD8+ T cells in vivo. J Exp Med 1991, 173:1463-1471

2. Rosenberg AS, Mizuochi T, Singer A: Cellular interactions resulting in skin-allograft rejection. Ann N Y Acad Sci 1988, 532:76-85

3. Rosenberg AS, Mizuochi T, Sharrow SO, Singer A: Phenotype, specificity, and function of T cell subsets and T cell interactions involved in skin allograft rejection. J Exp Med 1987, 165:1296-1315

4. Chan SY, DeBruyne LA, Goodman RE, Eichwald EJ, Bishop DK: In vivo depletion of CD8+ T cells results in Th2 cytokine production and alternate mechanisms of allograft rejection. Transplantation 1995, 59:1155-1161

5. Csencsits KL, Bishop DK: Contrasting alloreactive CD4+ and CD8+ T cells: there's more to it than MHC restriction. Am J Transplant 2003, 3:107-115

6. Krieger NR, Yin DP, Fathman CG: CD4+ but not CD8+ cells are essential for allorejection. J Exp Med 1996, 184:2013-2018

7. Grewal IS, Flavell RA: The role of CD40 ligand in costimulation and T-cell activation. Immunol Rev 1996, 153:85-106

8. Ridge JP, Di Rosa F, Matzinger P: A conditioned dendritic cell can be a temporal bridge between a CD4+ T-helper and a T-killer cell. Nature 1998, 393:474-478

9. Schoenberger SP, Toes RE, van der Voort El, Offringa R, Melief CJ: T-cell help for cytotoxic T lymphocytes is mediated by CD40-CD40L interactions. Nature 1998, 393:480-483

10. Curtsinger JM, Johnson CM, Mescher MF: CD8 T cell clonal expansion and development of effector function require prolonged exposure to antigen, costimulation, and signal 3 cytokine. J Immunol 2003, 171:5165-5171

11. Burrell BE, Lu G, Li XC, Bishop DK: OX40 costimulation prevents allograft acceptance induced by CD40-CD40L blockade. J Immunol 2009, 182:379-390

12. Nathan MJ, Mold JE, Wood SC, Csencsits K, Lu G, Eichwald EJ, Bishop DK: Requirement for donor and recipient CD40 expression in cardiac allograft rejection: induction of Th1 responses and influence of donor-derived dendritic cells. J Immunol 2004, 172: 6626-6633

13. Fischbein MP, Ardehali A, Yun J, Schoenberger S, Laks H, Irie Y, Dempsey P, Cheng G, Fishbein MC, Bonavida B: CD40 signaling replaces $\mathrm{CD} 4+$ lymphocytes and its blocking prevents chronic rejection of heart transplants. J Immunol 2000, 165:7316-7322
14. Strainic MG, Liu J, Huang D, An F, Lalli PN, Muqim N, Shapiro VS, Dubyak GR, Heeger PS, Medof ME: Locally produced complement fragments $\mathrm{C} 5 \mathrm{a}$ and $\mathrm{C} 3 \mathrm{a}$ provide both costimulatory and survival signals to naive CD4+ T cells. Immunity 2008, 28:425-435

15. Lalli PN, Strainic MG, Yang M, Lin F, Medof ME, Heeger PS: Locally produced $\mathrm{C} 5 \mathrm{a}$ binds to $\mathrm{T}$ cell-expressed C5aR to enhance effector T-cell expansion by limiting antigen-induced apoptosis. Blood 2008, 112:1759-1766

16. Heeger PS, Lalli PN, Lin F, Valujskikh A, Liu J, Muqim N, Xu Y, Medof ME: Decay-accelerating factor modulates induction of $\mathrm{T}$ cell immunity. J Exp Med 2005, 201:1523-1530

17. Lin F, Fukuoka Y, Spicer A, Ohta R, Okada N, Harris CL, Emancipator SN, Medof ME: Tissue distribution of products of the mouse decayaccelerating factor (DAF) genes. Exploitation of a Daf1 knock-out mouse and site-specific monoclonal antibodies. Immunology 2001, 104:215-225

18. Lalli PN, Strainic MG, Lin F, Medof ME, Heeger PS: Decay accelerating factor can control T cell differentiation into IFN-gamma-producing effector cells via regulating local C5a-induced IL-12 production. J Immunol 2007, 179:5793-5802

19. Pavlov V, Raedler H, Yuan S, Leisman S, Kwan WH, Lalli PN, Medof ME, Heeger PS: Donor deficiency of decay-accelerating factor accelerates murine T cell-mediated cardiac allograft rejection. J Immunol 2008, 181:4580-4589

20. Raedler H, Yang M, Lalli PN, Medof ME, Heeger PS: Primed CD8 T-cell responses to allogeneic endothelial cells are controlled by local complement activation. Am J Transplant 2009, 9:1784-1795

21. Chen Y, Demir Y, Valujskikh A, Heeger PS: Antigen location contributes to the pathological features of a transplanted heart graft. Am J Pathol 2004, 164:1407-1415

22. Fang $C$, Zhang $X$, Miwa $T$, Song WC: Complement promotes the development of inflammatory T-helper 17 cells through synergistic interaction with Toll-like receptor signaling and interleukin-6 production. Blood 2009, 114:1005-1015

23. Liu J, Lin F, Strainic MG, An F, Miller RH, Altuntas CZ, Heeger PS, Tuohy VK, Medof ME: IFN-gamma and IL-17 production in experimental autoimmune encephalomyelitis depends on local APC-T cell complement production. J Immunol 2008, 180:5882-5889

24. Marsh JE, Farmer CK, Jurcevic S, Wang Y, Carroll MC, Sacks SH: The allogeneic $T$ and $\mathrm{B}$ cell response is strongly dependent on complement components C3 and C4. Transplantation 2001, 72: $1310-1318$

25. Suresh M, Molina H, Salvato MS, Mastellos D, Lambris JD, Sandor M: Complement component 3 is required for optimal expansion of CD8 T cells during a systemic viral infection. J Immunol 2003, 170:788-794

26. Kopf M, Abel B, Gallimore A, Carroll M, Bachmann MF: Complement component $\mathrm{C} 3$ promotes $\mathrm{T}$-cell priming and lung migration to control acute influenza virus infection. Nat Med 2002, 8:373-378

27. Fang C, Miwa T, Shen H, Song WC: Complement-dependent enhancement of CD8+ T cell immunity to lymphocytic choriomeningitis virus infection in decay-accelerating factor-deficient mice. J Immunol 2007, 179:3178-3186

28. Qiao G, Lei M, Li Z, Sun Y, Minto A, Fu YX, Ying H, Quigg RJ, Zhang $\mathrm{J}$ : Negative regulation of CD40-mediated $\mathrm{B}$ cell responses by E3 ubiquitin ligase Casitas-B-lineage lymphoma protein-B. J Immunol 2007, 179:4473-4479

29. Hanissian SH, Geha RS: Jak3 is associated with CD40 and is critical for CD40 induction of gene expression in B cells. Immunity 1997, 6:379-387

30. Revy P, Hivroz C, Andreu G, Graber P, Martinache C, Fischer A, Durandy A: Activation of the Janus kinase 3-STAT5a pathway after CD40 triggering of human monocytes but not of resting B cells. J Immunol 1999, 163:787-793

31. Elgueta R, Benson MJ, de Vries VC, Wasiuk A, Guo Y, Noelle RJ: Molecular mechanism and function of CD40/CD40L engagement in the immune system. Immunol Rev 2009, 229:152-172

32. Wherry EJ, Ha SJ, Kaech SM, Haining WN, Sarkar S, Kalia V, Subramaniam S, Blattman JN, Barber DL, Ahmed R: Molecular signature of CD8+ T cell exhaustion during chronic viral infection. Immunity 2007 $27: 670-684$ 